\title{
KEKERASAN POLITIK ATAS NAMA AGAMA DAN PERAN KYAI DALAM KONSTELASI POLITIK DAERAH: MENELUSURI AKAR KONFLIK JEPARA 7 JULI 1998
}

\section{POLITICAL VIOLENCE ON THE NAME OF RELIGION AND THE ROLE OF KYAI IN REGIONAL POLITICAL CONSTELATION: TRACKING THE ROOTS OF THE JEPARA CONFLICT 7 JULY 1998}

\author{
Hidayatullah Rabbani \\ Pusat Penelitian Masyarakat dan Budaya-LIPI \\ Lembaga Ilmu Pengetahuan Indonesia \\ hidayatullahrabbani@gmail.com
}

Artikel diterima 30 April 2019, diseleksi 17 Mei 2019, dan disetujui 12 Desember 2020

\begin{abstract}
The Jepara riot on July 7, 1998 was one of the impacts of the reforms at the local level that began in May in the same year. This riot has claimed lives, significant material and immaterial losses. The cause of this riot was the politicization of religion in the political field. To study this problem, the critical historical method is used which includes four steps, namely heuristics, criticism, synthesis and historiography. The data mining technique uses written primary sources in the form of archives from other contemporary reports, such as newspapers and magazines. Oral primary sources are obtained through direct interviews with competent people. Secondary sources are obtained through literature study of books by relevant scholars and experts or other forms of publication. The results showed that the role of the Kyai in politics in Jepara was very large in directing his followers to determine their political direction. The emergence of a plan to form a new party among NU residents has divided Jepara society. The culmination of this split led to the rioting on July 7 1998. This paper is a development of the author's thesis entitled Kyai, Politics, and Violence: Riots in Jepara 1998.
\end{abstract}

Keywords: Kyai, Politics, Riot, Jepara

\begin{abstract}
Abstrak
Kerusuhan Jepara 7 Juli 1998 merupakan salah satu dampak reformasi di tingkat lokal yang bergulir sejak bulan Mei di tahun yang sama. Kerusuhan ini telah menelan korban jiwa, kerugian material dan immaterial cukup besar. Penyebab kerusuhan ini adalah adanya politisasi agama di bidang politik. Untuk mengkaji permasalahan itu digunakan metode sejarah kritis yang mencakup empat langkah yaitu heuristik, kritik, sintesis dan historiografi. Teknik penggalian data menggunakan sumber primer tertulis yang berupa arsip dari laporan sejaman lain, seperti koran dan majalah. Sumber primer lisan diperoleh melalui wawancara secara langsung dengan orang-orang yang berkompeten. Sumber sekunder diperoleh melalui studi pustaka terhadap buku-buku karya para sarjana dan ahli yang relevan atau bentuk penerbitan yang lain. Hasil penelitian menunjukkan peran Kyai dalam politik di Jepara sangat besar untuk mengarahkan para pengikutnya menentukan arah politiknya. Munculnya rencana pembentukan partai baru dikalangan warga NU membuat masyarakat Jepara terbelah. Kulminasi dari perpecahan tersebut memunculkan aksi kerusuhan 7 Juli 1998. Tulisan ini merupakan pengembangan dari skripsi penulis berjudul Kyai, Politik, dan Kekerasan: Kerusuhan di Jepara Tahun 1998.
\end{abstract}

Kata Kunci: Kyai, Politik, Kerusuhan, Jepara 


\section{PENDAHULUAN}

Sejak Indonesia merdeka pada 17 Agustus 1945 kondisi politik nasional selalu mengalami perubahan. Perubahan tersebut secara langsung maupun tidak langsung memiliki pengaruh yang besar terhadap kehidupan rakyat Indonesia. Kebijakan politik tingkat pusat sering kali memberi dampak negatif pada wilayah lokal yang pada akhirnya rakyat menjadi korban. Perbedaan ideologi, persaingan antar partai politik yang memperebutkan kekuasaan hampir selalu mewarnai kehidupan bangsa Indonesia. Kondisi tersebut membawa bangsa Indonesia ke ambang perpecahan. Partai politik yang pada awal pembentukannya bertujuan agar segala aliran paham di masyarakat dapat dipimpin ke jalan yang teratur dan dapat berguna bagi perjuangan bangsa Indonesia (Tim Sekretaris Negara, 1983), namun dalam perjalanannya, partai-partai politik saling bersaing meraih kekuasaan dan mengutamakan kepentingan kelompoknya.

Menjelang berakhirnya pemerintahan Orde Baru sampai awal Reformasi, kesadaran kolektif sebagai bangsa Indonesia yang berdaulat sebagaimana ditanamkan secara gemilang oleh para founding fathers, seakan sirna. Di beberapa wilayah, konflik antar suku, ras, agama, kelompok, dan antar golongan terus berkobar dan tidak sedikit disertai jatuhnya korban jiwa (Turmudi, 2000). Lunturnya rasa persatuan dan kesatuan sebagai bangsa Indonesia diakibatkan oleh beberapa sebab, di antaranya konflik antar partai politik.

Pada masa Orde Baru persaingan antar-partai politik mendapat perhatian pemerintah, sehingga dikeluarkan berbagai kebijakan politik. Menurut pemerintah, banyaknya partai poltik dari beragam aliran membawa dampak ketidakstabilan politik nasional dan menghambat kemajuan pembangunan bangsa. Pemerintah melalui UU No. 3
Tahun 1975 tentang Partai Politik dan Golkar melakukan penyederhanaan partai-partai politik, sehingga pada pemilu 1971 hanya terdapat 10 kontestan partai politik yaitu: Golkar, NU, Parmusi, PNI, PSII, Parkindo, Katolik, Perti, IPKI, dan Murba (Haris, 1991). Faksi-faksi kelompok partai politik ini kemudian disederhanakan menjadi tiga partai yaitu (1) Partai Persatuan Pembangunan (PPP) merupakan penggabungan partaipartai Islam NU, Parmusi, PSII, dan Perti, (2) Partai Demokrasi Indonesia (PDI) merupakan penggabungan partaipartai nasionalis dan Kristen yaitu PNI, Parkindo, Katolik, Perti, IPKI, dan Murba, dan Golkar (Haris, 1991).

Partai-partai yang berasaskan Islam saat itu mulaimelakukan fusi untuk menyatukan barisan. Hal itulah tampaknya yang menjadi semangat K.H Idham Chalid dan K.H. Masykur dari NU, H.M.S. Mintaredja dari Parmusi, Anwar Tjokroaminoto dari PSII, dan Rusli Halil dari Perti tatkala menandatangani deklarasi pembentukan Partai Persatuan Pembangunan (PPP) pada 5 Januari 1973 (Haris, 1991). PPP merupakan partai politik yang di dalamnya terdapat berbagai aliran politik dan ideologi, walaupun tetap mengatasnamakan Islam sebagai asas kepartaian. Keberadaan PPP pada awalnya adalah untuk menyelamatkan suara partai-partai Islam yang pada pemilu 1971 mengalami kekalahan telak dari partai Golkar yang membawa isu pembangunan melalui slogan "Politik no, dan pembangunan yes". Namun kenyataan itu yang menjadi awal problematik PPP dalam pemilu-pemilu berikutnya, PPP hanya mengandalkan isu-isu agama untuk memanfaatkan emosi pemeluk Islam untuk tetap mendukung PPP sebagai satu-satunya partai Islam (Haris, 1991).

Kekompakan antar-aliran politik dalam tubuh PPP berlangsung kurang lebih sewindu sejak awal kehadirannya. 
Hal ini karena adanya tokoh pemersatu di antara semua aliran yang ada di tubuh PPP yaitu Kyai Bisri Syamsuri, Rois 'Aam, ketua umum majelis syuro Partai Persatuan Pembangunan (PPP) yang juga menjabat sebagai Rois 'Aam Syuriah pengurus besar Nahdlatul Ulama, Keberadaan Kyai Bisri dapat meredam berbagai perbedaan di tubuh PPP karena kepemimpinan partai tunduk pada majelis syuro, yang dalam kata lain, tingkah laku PPP masih bersumber pada referensi agama. Setelah Kyai Bisri meninggal, bibit-bibit konflik internal ditubuh PPP muncul kepermukaan, apalagi setelah PPP dipimpin oleh Jhon Naro pada 1984 yang melahirkan berbagai kontroversi. Naro secara sepihak mengubah susunan pengurus pusat partai tanpa musyawarah dengan unsur partai lain (Shobron, 2003). Hal ini yang membuat para tokoh NU kecewa karena merasa disingkirkan dari tubuh PPP. Padahal sumber massa terbesar PPP berasal dari golongan NU. Tekanan pemerintah Orde Baru terhadap ormas dan partai politik, serta munculnya generasi muda NU yang kritis menjadi alasan penarikan NU dari PPP semakin kuat (Khalik, 2016).

Penarikan NU dari PPP semakin ditegaskan pada Muktamar alim ulama NU yang diselenggarakan di Situbondo pada akhir 1984 (Haris, 1991). Muktamar tersebut mengeluarkan dua keputusan penting yaitu NU menarik diri dari politik praktis dan mengikuti tuntunan asas tunggal Pancasila (Turmudi, 2016). Keputusan muktamar di Situbondo juga menegaskan bahwa NU kembali ke Khittah 1926. NU memberikan kebebasan kepada warganya termasuk para Kyai, untuk menyalurkan aspirasi politik mereka tidak harus ke PPP. Akibat dari keluarnya NU dari kancah politik nasional menyebabkan dukungan warga NU terhadap PPP menjadi terpecah. Warga NU ada yang tetap di PPP dan ada yang memilih partai lain seperti Golkar dan PDI (Haris, 1991).
Memasuki era reformasi setelah berakhirnya kekuasaan Orde Baru pada Mei 1998 ditandai dengan euforia politik yang terjadi diberbagai lapisan masyarakat Indonesia (Marijan, 2019). Di tingkat pusat para elit politik yang ketika Orde Baru berkuasa merasa tersingkirkan, mulai merencanakan pembentukan partai-partai baru sebagai bentuk sikap kebebasan politik (Humaedi, 2015). Tokoh-tokoh politik tersebut diantaranya berasal dari golongan NU yang juga bergabung dalam PPP, namun tidak mendapat posisi yang diinginkan selama di PPP, sehingga para elite tersebut berencana membentuk partai yang bisa menjadi wadah menyalurkan aspirasi warga NU sendiri. Rencana pembentukan partai baru tersebut berkembang luas di kalangan nahdliyin, di sisi lain PPP yang basis massa terbesarnya berasal dari warga NU merasa khawatir karena kehadiran partai dari kalangan NU bisa menurunkan jumlah dukungan massa terhadap PPP. Tokoh politik dan Kyai yang berafiliasi dengan PPP khawatir akan rencana tersebut, sehingga mereka melakukan berbagai cara agar dapat menarik simpati dari warga NU melalui ceramah-ceramah pengajian yang gencar diadakan di berbagai wilayah, tidak terkecuali wilayah Jepara yang merupakan basis massa NU. Persaingan politik yang berujung konflik antar warga NU terjadi hingga tingkat lokal. Salah satu wilayah yang terkena dampak dari konflik politik tersebut adalah kabupaten Jepara.

Masyarakat Jepara berbeda dengan masyarakat lainnya dalam arti sikap dan perilaku politik yang konsisten dan memiliki keberanian dalam berperilaku sesuai apa yang diyakini (Turmudi, 2000). Hal ini sesuai dengan karakter Jepara yang merupakan wilayah pesisir yang terbuka dan blak-blakan. Wilayah Jepara sejak sebelum kemerdekaan merupakan basis massa NU, sehingga sikap politik masyarakat Jepara cenderung menjadikan 
NU sebagai kendaraan politik. Konsistensi sikap politik warga NU lebih condong ke partai yang berafiliasi dengan Islam sebagai asas perjuangan partai. Masyarakat Islam Jepara memiliki tingkat kefanatikan yang cukup tinggi terhadap NU dan PPP sebagai kendaraan politiknya. Hal tersebut tidak terlepas dari peranan para kyai dan pesantren sebagai basis massa. Tokoh kyai dalam masyarakat Islam Jepara merupakan elemen yang paling esensial dalam kehidupan bermasyarakat (Sahidin, 2001). Kyai sebagai pemimpin informal memiliki pengaruh yang cukup penting dalam masyarakat Jepara. Pengaruhnya tidak hanya dalam bidang keagamaan namun juga kultural dan politik.

Ketika tokoh kyai di Jepara terjun dalam dunia politik praktis, pengetahuan yang dimiliki oleh seorang Kyai merupakan kekuatan yang potensial yang dapat digunakan tidak hanya untuk menggalang dukungan umat secara keseluruhan guna mewujudkan suatu tindakan atau proses politik tertentu, tetapi bahkan untuk mendukung suatu politik kekuasaan politik tertentu. Berkat aura kharismatik yang dimilikinya, kehadiran kyai dalam suatu pertemuan politik, semacam kampanye, apalagi jika disertai himbauan oleh kyai untuk mendukung partai atau kekuatan politik tertentu, bagi masyarakat Jepara yang merupakan massa mengambang (floating mass) bukan sekedar keputusan politik, tetapi sekaligus merupakan fatwa keagamaan (Sahidin, 2001). Ketika terjadi segmentasi kyai dalam kehidupan politik praktis setelah Orde Baru runtuh, di mana sebagian berafiliasi ke PPP dan pada bagian lain berafilialisi ke partai yang akan didirikan pengurus NU pusat.

Setelah Orde Baru runtuh, pengurus NU merencanakan pembentukan partai baru bagi kalangan NU dengan tujuan sebagai wadah politik bagi warga NU. Namun pendirian partai ini menimbulkan berbagai polemik di antara warga NU. Salah satu yang dipermasalahkan adalah bahwa pendirian parti baru dari kalangan pengurus NU bertentangan dengan hasil Muktamar di Situbondo tahun 1984 yang menegaskan bahwa NU tidak terjun dalam politik praktis (Shobron, 2003). Namun dalam kasus kerusuhan Jepara pada 7 Juli 1998, Partai dari kalangan NU belum didirikan secara resmi, tetapi baru berupa wacana dan rencana oleh para elit NU tingkat Pusat. Rencana pendirian partai baru dari kalangan NU tersebut membuat kekhawatiran tersendiri bagi sebagian warga NU yang berafiliasi ke PPP. Kekhawatiran tersebut wajar karena adanya kesamaan basis massa yang diperebutkan yaitu massa NU.

Masyarakat Islam Jepara terbelah menjadi dua kelompok pendukung, yaitu pendukung PPP dan pendukung embrio partai NU. Kedua kelompok besar tersebut sama-sama dengan argumen mengikuti jejak dan nasihat Kyai. Sebagian besar masyarakat Jepara merupakan pendukung PPP, sedangkan sebagian masyarakat Islam lain misalnya para pengurus organisasi NU dengan alasan mengikuti Kyai yang lebih besar mendukung embrio pembentukan partai bagi kalangan NU. Keadaan tersebut membuat masyarakat Islam Jepara terjebak pada segregasi sosial yang sangat tajam karena perbedaan kepartaian.

Ketika para kyai yang terjun dalam politik praktis menggunakan ajaran agama untuk melegitimasi suatu pandangan tertentu atau dalam kata lain politisasi agama untuk menyosialisasikan pandangan politiknya, maka timbullah konflik antar partisan yang mengarah pada tindakan kekerasan. Peristiwa kerusuhan di Jepara pada 7 Juli 1998 merupakan akumulasi konflik yang ada di masyarakat yang telah mencapai titik kulminasi sehingga timbul gejolak. Untuk mengungkap bagaimana peristiwa tersebut sampai terjadi maka dalam 
tulisan ini permasalahan yang diangkat meliputi; Bagaimana kontestasi partai politik yang mengatasnamakan agama dalam konteks Jepara?; Bagaimana peran Kyai dalam kontestasi dan penyelesaian konflik?; Bagaimana membangun rekonsiliasi kelompok-kelompok dalam kepentingan elektoral?

Pembatasan ruang lingkup dalam penelitian sejarah diperlukan agar penelitian dapat lebih terfokus dan hasilnya dapat dipertanggungjawabkan secara empiris dan metodologis (Abdullah, 1990). Penelitian sejarah mengenal tiga ruang lingkup, yakni temporal, spasial, dan keilmuan. Lingkup temporal tulisan ini adalah tahun 1998 tepatnya menjelang tanggal 7 Juli 1998. Tanggal 7 Juli 1998 dipilih sebagai batas kajian dengan alasan bahwa pada tanggal tersebut merupakan puncak dari konflik politik yang terjadi di masyarakat Jepara. Peristiwa yang dibahas ini merupakan peristiwa lokal, maka dengan sendirinya lingkup spasialnya juga akan meliputi batas geografis yang terbatas pula, karena peristiwanya di Jepara maka analisis peristiwa kerusuhan tersebut akan difokuskan untuk daerah Jepara yang merupakan tempat terjadinya peristiwa. Sementara itu, lingkup keilmuan yang diambil dalam penulisan ini yaitu Sejarah Sosial Politik (Kartodirjo, 1982). Hal ini akan membut penulisan lebih bersifat komprehensif, dan memudahkan penulis memahami suatu peristiwa sejarah politik.

Tulisan ini membahas tentang Kerusuhan Jepara 7 Juli 1998 yang dilatarbelakangi oleh konflik politik antar pendukung partai Islam di Jepara. Kerusuhan (riot) didefinisikan sebagai 'pecahnya' kekacauan massa yang singkat namun sarat kekerasan. Kekerasan pecah secara tiba-tiba, membakar, dan mengamuk terhadap kelompok sasaran dan kemudian mereda dalam waktu singkat setelah meninggalkan korban dan kehancuran (Singh, 2010). Kerusuhan merupakan puncak dari ketidakpuasan umum yang terjadi dalam masyarakat. Kerusuhan bisa pecah karena isu-isu agama, sektarian, komunal, ekonomi, politik atau rasial.Menurut Kamus Besar Bahasa Indonesia kerusuhan adalah aksi kolektif yang spontan, tidak terorganisir, tidak bertujuan, yang biasanya melibatkan penggunaan kekerasan, baik untuk menghancurkan, menjarah barang, atau menyerang orang lain (Indonesia, 2005). Dalam kerusuhan seperti itu, keterlibatan para aktor lapangan biasanya akan mudah terdeteksi. Namun, aktor intelektual paling sulit untuk ditemukan. Dalam konteks kerusuhan Jepara, banyak informasi yang beredar bahwa ada keterlibatan tokoh-tokoh agama di dalamnya.

Kerusuhan Jepara pada 7 Juli 1998 tidak terlepas dari peranan kyai. Istilah kyai memiliki pemaknaan yang beragam dari sisi istilah, secara umum "kyai" diartikan sebagai penyebutan kepada seseorang yang dihormati karena memiliki ilmu keagamaan, Namun istilah kyai oleh beberapa ahli masih memiliki beragam arti. Menurut Zamakhsyari Dhofier (Dhofier, 1982), istilah kyai dipakai untuk tiga jenis gelar yang saling berbeda. Pertama, sebagai gelar kehormatan bagi barang-barang yang dianggap keramat umpamanya " Kyai garuda kencana" dipakai untuk nama kereta emas yang ada di keraton Yogyakarta. Kedua, gelar kehormatan untuk orang-orang tua pada umumnya. Ketiga, gelar yang diberikan masyarakat kepada seorang ahli dalam agama Islam yang memiliki atau memimpin pesantren dan mengajarkan kitab-kitab Islam klasik kepada para santrinya. Akan tetapi sebutan kyai juga ditujukan kepada mereka yang mengerti ilmu agama tanpa memiliki lembaga pondok pesantren atau menetap dan mengajarkan di pondok pesantren (Sukamto, 1999). 
Menurut Cholil Bisri seseorang yang dikatakan atau mendapat julukan sebagai kyai adalah orang yang oleh masyarakat dianggap sebagai orang alim (Bisri, 1999). Jadi Alim adalah orang yang berilmu dan ulama adalah orang-orang yang punya ilmu. Penggunaan istilah kyai sendiri hanya berlaku dalam kultur masyarakat Indonesia, khususnya masyarakat Jawa. Disini kyai memainkan peranan yang penting, baik dalam pendidikan agama maupun peristiwa-peristiwa keagamaan pada umumnya. Dalam hal ini, Horikoshi menyebutkan ada perbedaan antara kyai dan ulama, yang dibedakan dalam peran dan pengaruhnya di masyarakat. Ulama adalah istilah yang lebih umum dan merujuk kepada seorang muslim yang berpengetahuan. Kaum ulama adalah kelompok yang secara jelas mempunyai fungsi dan peran sosial sebagai cendikiawan penjaga tradisi yang dianggap sebagai dasar identitas primodial individu dan masyarakat (Horikoshi, 1987). Oleh karena itu, pengertian ulama lebih memerankan fungsi administratif, sedangkan kyai cenderung bermain pada tataran kultural. Kyai di Jepara merujuk pada gelar yang diberikan oleh masyarakat terhadap seseorang yang ahli dalam bidang agama, dan memiliki pengetahuan mengenai kehidupan sosial masyarakat yang mencakup tradisi, hingga urusan politik.

Untuk mengungkap latar belakang dan mencari faktor-faktor kausalitas, proses, serta akibat dari peristiwa kerusuhan di Jepara pada 7 Juli 1998, perlu digunakan pendekatan historis (Garraghan, 1946). Pendekatan Historis mampu mengungkapkan korelasi, kecenderungan, serta pola perkembangan fenomena yang terjadi. Dengan mengkaji peristiwa kerusuhan tersebut akan dapat diungkapkan kausalitas dan proses terjadinya kerusuhan yang saling terkait di dalamnya (Hajati \& Kartodirdjo, 1990).
Penelitian ini menggunakan teori gerakan sosial yang sesuai dengan tema penulisan, yaitu teori Neil J. Smelser, Theory of Colective Behavior (Smelser, 2011). Tingkah laku kolektif (Colective Behavior) dapat berbentuk perilaku kerumunan (crowd), dan gerakan sosial. Kerusuhan di Jepara pada 7 Juli 1998 merupakan tindakan sosial dari masyarakat dan masuk dalam bentuk perilaku kerumunan.

Menurut Smelser, determinandeterminan yang dapat menimbulkan tingkah laku kolektif (collective behavior), yang memunculkan suatu gerakan adalah:

Pertama, Structural conduciveness, yaitu situasi yang mendorong atau mempercepat timbulnya gerakan atau suatu keadaaan dimana ikatan-ikatan struktur sosial tidak begitu kuat lagi, sehingga banyak orang yang dapat memperoleh apa yang dikehendakinya kapan saja dia mau. Tidak adanya kepastian hukum, tidak ditaatinya peraturan-peraturan yang berlaku, merupakan ciri-ciri determinan ini.

Kondisi struktural yang dimaksud adalah situasi negara Indonesia pada tahun 1998 mengalami krisis dalam berbagai bidang. Namun krisis menyebabkan terjadi gejolak di masyarakat adalah krisis kepercayaan. Masyarakat tidak percaya lagi dengan pemerintah dan elite politik dalam upaya mengatasi krisis. Ketidakpercayaan masyarakat terhadap pemerintah terjadi hampir di seluruh kota, tidak terkecuali di Jepara. Munculnya gerakan pro dan kontra terhadap pelarangan ceramah kyai merupakan akibat dari ketidakmampuan kontrol sosial pemerintah dan elit politik dalam mengakomodasi tuntutan warganya. Masyarakat tidak percaya dengan aparat pemerintah Jepara hal ini terjadi akibat dari kebijakan yang selama ini dijalankan oleh pemerintah Jepara yang sering bertindak diskriminatif terhadap warganya. 
Kedua, Structuralstrain, yaitu ketegangan struktural yang muncul dan mendorong munculnya suatu gerakan. Ketegangan struktural merupakan hasil kristalisasi dari kondisi struktural. Ketegangan struktural yang dimaksud adalah adanya kekawatiran sebagian warga NU yang berafiliasi dengan PPP terhadap kemunculan partai baru dari kalangan NU sehingga dikhawatirkan dapat merebut basis massa PPP di Jepara yang sebagian besar berasal dari warga NU. Kemudian para elite PPP melakukan berbagai cara untuk menarik simpati massa dengan menghadirkan Kyai yang menurut sebagian masyarakat Jepara sering melontarkan kata-kata kurang pantas sehingga memunculkan pro dan kontra dalam masyarakat Jepara yang diekspresikan dengan demonstrasi, sehingga muncul gesekan antar pendukung yang kemudian adanya ulah provokatif, sehingga memicu kerusuhan.

Ketiga, Growthand spread of general belief (penyebaran keyakinan umum), yaitu sebelum suatu perilaku kolektif muncul, para pelaku perilaku kolektif harus mempunyai pandangan dan keyakinan umum yang sama mengenai sumber ancaman, jalan keluar, dan cara pencapaiaan jalan keluar tersebut. Dalam kasus kerusuhan pada 7 Juli 1998 di Jepara keyakinan umum yang tersebar di masyarakat yang mendukung PPP bahwa segala aktivitas mereka merupakanibadah yang harus dilaksanakan termasuk dalam hal berpolitik. Perkataan Kyai dijadikan semacam fatwa yang menurut keyakinan mereka berasal dari ajaran Quran dan Hadits. Masyarakat Islam Jepara belum bisa membedakan antara wilayah politik dan wilayah agama sehingga ketika ada kelompok masyarakat yang menolak kehadiran kyai yang dianggap provokatif di Jepara yang menurut mereka "kurang pantas" dalam menyampaikan ceramah di tengah masyarakat, maka oleh para pendukung PPP dan para kyai tersebut melakukan protes balasan karena dianggap menghalangi dakwah Islam.
Keempat, Precipitating factors atau faktor pencetus yaitu suatu peristiwa dramatis atau desas-desus yang mempercepat munculnya perilaku kolektif atau gejolak sosial. Munculnya isu yang berkembang di tengah masyarakat Jepara bahwa pelarangan pengajian di Jepara didalangi oleh Bupati Jepara dengan memobilisasi kepala desa di kecamatan Tahunan Jepara pada demo penolakan kehadiran kyai tersebut pada 1 Juli 1998, Bupati telah menegeluarkan surat pernyataan yang membantah adanya pelarangan tersebut. Namun masyarakat sudah terlajur terbakar emosinya dengan adanya isu tersebut. Masyarakat tidak mempercayai Bupati dan aparat pemerintah.

Kelima, Mobilization of participant for action, adalah mobilisasi pengikut yang mengadakan aksi, termasuk didalamnya adalah adanya pemimpin yang menggerakkan massa itu sendiri. Demonstrasi yang dilakukakan pada 7 Juli 1998 dan berujung pada kerusuhan pada awalnya hanya memprotes adanya isu pelarangan ceramah Kyai Affifudin oleh sebagian masyarakat Jepara yang melakukan demonstrasi pada 1 Juli 1998 di DPRD Jepara. Kehadiran massa demonstrasi tidak hanya memprotes larangan ceramah, namun diantara massa demonstran ada yang datang karena adanya informasi akan diadakan pengajian yang akan dihadiri oleh Kyai Affifudin di alun-alun Jepara sehingga massa yang datang berjumlah hingga ribuan orang dan tidak hanya kaum laki yang datang namun juga ada wanita dan orang tua. Jadi dapat disimpulkan bahwa mobilisasi massa dalam aksi demonstrasi yang berakhir pada kerusuhan tersebut karena adanya sosok yang dianggap jadi pemimpin dalam hal ini Kyai Affifudin sehingga muncul gerakan massa dimasyarakat dengan berbagai tujuan.

Keenam, Lack of social control, atau mekanisme berlakunya kontrol sosial 
yang dilakukan oleh pemimpin gerakan, kekuatan aparat keamanan, kebijakan pemerintah hingga kontrol sosial lainnya. Demontrasi pada 7 Juli 1998 yang memprotes adanya larangan ceramah tersebut yang kemudian berujung pada kerusuhan terjadi akibat kontrol sosial yang kurang, baik oleh pemimpin gerakan, masyarakat, pemerintah maupun aparat keamanan. Pemerintah Jepara yang merupakan pemegang kekuasaan kontrol sosial terbesar kurang memperhatikan konflik yang terjadi dimasyarakatnya, adanya persaingan poitik dan munculnya ulah provokator tidak segera diredam oleh pemerintah sehingga ketika adanya gejolak maka pemerintah tidak siap dalam menanganinya.

Kontrol sosial yang dilakukan oleh pemerintah Jepara dan pemimpin gerakan serta kelompok yang bertikai hanya berlangsung pada tingkat elite dan tidak berpengaruh terhadap massa yang merupakan sumber konflik tersebut, sehingga ditingkat bawah konflik terus berlangsung. Misalnya, muncul sikap saling curiga dimasyarakat karena perbedaan pandangan politik.

\section{METODE}

Metode penulisan yang digunakan adalah metode sejarah, yaitu heuristik, kritik, interpretasi dan historiografi (Gottschalk \& Notosusanto, 1985). Pada tahap awal, penulis melakukan pengumpulan sumber primer dan sumber sekunder, sumber primer tertulis yang berupa arsip dari laporan sejaman penulis dapatkan dari beberapa surat kabar yang terbit pada waktu itu seperti Suara Merdeka, Kompas, Suara Pembaharuan, Gatra, Pikiran Rakyat, Republika, dan Suara Karya. Sumber primer lisan diperoleh melalui wawancara secara langsung dengan orang-orang yang berkompeten. Hasil wawancara ini digunakan sebagai pelengkap dan sekaligus pembanding sumber tertulis. Hasil wawancara beberapa tokoh yang representatif diseleksi dan dibanding-bandingkan, sehingga akan diperoleh datayang objektif. Wawancara dilakukan dengan para informan yang dapat dibedakan ke dalam tiga kategori, yaitu: (i) orang-orang yang terlibat langsung dalam peristiwa; (ii) orang-orang yang menyaksikan peristiwa, tetapi tidak terlibat langsung didalamnya; dan (iii) orangorang yang tidak terlibat dalam peristiwa, tetapi mendapat keterangan dari orang yang terlibat dalam peristiwa.

Sumber lain yang digunakan yaitu sumber sekunder. Sumber sekunder diperoleh melalui studi pustaka terhadap buku-buku karya para sarjana dan ahli yang relevan serta artikel- artikel yang dimuat dalam majalah dan surat kabar sezaman atau bentuk penerbitan yang lain. Sumber-sumber ini berguna untuk melengkapi sumber-sumber primer dalam rangka memperoleh pemahaman yang lebih mendalam mengenai peristiwa yang diteliti.

Penelitian artikel ini dikhususkan pada pembahasan kontestasi keagamaan dalam ruang politik di Jepara tahun 1998. Beberapa karya tulis ilmiah yang berkaitan dengan hal ini diantaranya skripsi yang berjudul Kerusuhan Sosial di Desa Dongos Kecamatan Kedung Kabupaten Jepara Tahun 1999 ditulis oleh Ahmad Zazeri (Zazeri, 2007). Demikian juga makalah yang berjudul Reformasi dan Konflik Politik Antar Pendukung Partai Islam ditulis oleh Endang Turmudi (Turmudi, 2000). Selain itu, ada beberapa buku yang berkaitan dengan kontestasi antara agama dan politik diantaranya yaitu Kyai dan Pembangunan Institusi Sosial ditulis oleh Sayfa Auliya Achidsti (Achidsti, 2015), Kyai dan Politik ditulis oleh Muh Syamsuddin (Syamsuddin, 2013), PPP dan Politik Orde Baru ditulis oleh Sjamsuddin Haris (Haris, 1991). 


\section{PEMBAHASAN}

\section{Jepara: Sebuah Arena Kontestasi}

Jepara merupakan wilayah pesisir yang penduduknya memiliki sikap keterbukaan yang tinggi terhadap dunia luar. Hal itu yang menjadi salah satu faktor yang mempengaruhi kondisi kultural keagamaan masyarakat Jepara. Letak Kabupaten Jepara yang berdekatan dengan Demak yang ketika abad ke-16 merupakan pusat penyebaran Islam di pulau Jawa membawa pengaruh terhadap kondisi kultural keagamaan masyarakat Jepara. Sebagian besar masyarakat Jepara merupakan penganut agama Islam yang taat dan juga merupakan basis massa kaum Nahdlatul Ulama (NU) (Turmudi, 2000). NU sendiri adalah suatu jamiyah yang didirikan tahun 1926 di Surabaya dan bertujuan mempertahankan paham Ahlussunnah Wal-Jamaah dengan mengikuti madzab Imam Syafi'i dalam fiqh, dalam bidang aqidah bersandar pada Al-Asy'ari, dan dalam bidang tasawuf berpegang pada Imam al- Ghazali, serta peran ulama-kyai sebagai pemimpin informal (Turmudi, 2004).

Berdasarkan data statistik masyarakat Jepara yang menganut agama Islam meliputi hampir $95 \%$ dari total jumlah penduduk dan dilanjutkan oleh agama Kristen, Budha, Katholik dan Hindu. Berikut ini penyebaran jumlah penduduk di Jepara berdasarkan menurut agama yang dianut. Menurut data BPS Jepara tahun 1998, jumlah penduduk Jepara paling besar adalah pemeluk agama Islam yaitu sebanyak 841.675 orang, Kristen sebanyak 23.044 orang, Budha sebanyak 4.400 orang, Katholik sebanyak 1.700 orang, Hindu sebanyak 513 orang (Jepara, 1998).

Keberadaan ulama mendapat tempat terhormat dalam masyarakat Jepara. Ulama merupakan pemimpin informal yang sangat berpengaruh peranannya dalam segi kehidupan masyarakat Jepara. Jumlah ulama atau penyiar agama Islam di Jepara bedasarkan data BPS Jepara tahun 1998 dapat diketahui jumlah ulama sebanyak 1.108 orang, khotib sebanyak 2.067 dan mubaligh sebanyak 1.769 orang (Jepara, 1998). Jumlah ini menunjukkan bahwa keberadaan ulama sangat penting dalam masyarakat Islam di Jepara. Ajaranajaran tradisonal yang memberi tempat terhormat bagi ulama dan keberadaan ulama atau kyai dalam masyarakat Jepara ikut mempengaruhi pembentukan budaya, kehidupan sosial kemasyarakatan dan pandangan politik dalam masyarakat Islam Jepara. Kepemimpinan ulama atau kyai di Jepara mempunyai otoritas dalam kehidupan masyarakat, dibanding dengan kepemimpinan formal. Seorang kyai dipercaya mempunyai kharisma dan berada dalam posisi untuk memberi "kata putus" dalam memecahkan suatu persoalan atau masalah-masalah krusial dalam budaya pesantren (Dhofier, 1982).

Pembentukan kultural keagamaan di Jepara tidak terlepas dari keberadaan pesantren yaitu tempat para santri menuntut ilmu keagamaan Islam dibawah asuhan kyai/ulama. Biasanya santri bermukim disebuah tempat tinggal yang bernama pondok pesantren. Orientasi pendidikan warga nahdliyin di Jepara masih percaya kalau pendidikan agama lebih diutamakan dibanding dengan pendidikan formal yang diadakan pemerintah. Keberadaan pondok pesantren di Jepara menjadi sangat penting sebagai institusi pendidikan kegamaan (bandingkan dengan Turmudi, 2000). Banyaknya pondok pesantren dan santri di Kabupaten Jepara pada tahun 1998 sebanyak 108 pondok pesantren dengan jumlah murid/santri sebanyak $17.404 \mathrm{murid} /$ santri (Jepara, 1998).

Keberadaan pondok pesantren dan santri menunjukkan lembaga pendidikan keagamaan yang menjadi rujukan masyarakat Islam Jepara dalam 
menuntut ilmu. Pesantren di Jepara mayoritas adalah pesantren tradisonal yang beraliran Ahlussunnah Wal-Jamaah dan merupakan basis massa Nahdlatul Ulama. Hal ini tercermin dalam kitabkitab yang diajarkan (kitab kuning) dan pola pengajaran yang menempatkan ulama/kyai sebagai guru utama yang setiap perkataan dan tindakannya akan diikuti para santri dan pengikutnya (bandingkan dengan Turmudi, 2000).

Kehidupan politik masyarakat Jepara tidak terlepas dari peranan Nahdlatul Ulama dan para kyai-nya (Turmudi, 2000). Ini terjadi karena masyarakat Jepara secara mayoritas adalah anggota atau simpatisan NU yang cukup fanatik. Kuatnya pengaruh NU terhadap kehidupan politik masyarakat Jepara bisa dilihat dari beberapa hasil pemilu yang ada, meskipun terjadi penurunan dalam beberapa pemilu yang diadakan pemerintah orde baru. Perolehaan suara partai yang didukung NU yaitu PPP selalu mendapat posisi teratas dalam perolehan dukungan. PPP dianggap sebagai partai Islam dan merupakan satu-satunya saluran politik Islam (lihat Schiller, 1996). Keberadaan PPP sebagai partai Islam dianggap sejalan dengan politik Islam yang telah dijalankan NU sebelum PPP berdiri. Hal ini menjadikan PPP sebagai wadah perjuangan politik masyarakat Islam di Indonesia ketika orde baru.

Politik Islam yang dijalankan NU dan kemudian PPP dianggap sesuai dengan aspirasi masyarakat Jepara yang berharap dapat memperjuangkan Islam lewat politik dan keberaadan ulama atau kyai memiliki peran cukup besar dalam mempengaruhi masyarakat terhadap perilaku politiknya (bandingkan dengan Turmudi, 2000). Keberadaan ulama atau kyai di Jepara mendapat tempat yang terhormat dalam masyarakat karena keterikatan masyarakat terhadap Islam cukup kuat sehingga keberadaan kyai yang dipandang memiliki kecakapan dibidang keagamaan dan dianggap sebagai guru, sehingga masyarakat ikut terdorong untuk bersikap dan bertingkah laku sesuai anjuran para ulama termasuk bersikap sama dalam dunia politik.

Masyarakat Jepara telah menjadi masyarakat yang Islam oriented dilihat dari sisi perjuangan politik. Keberadaan partai Islam dalam hal ini PPP oleh sebagian masyarakat Jepara telah menjadi agama sendiri, yaitu pentingnya menjaga politik Islam dan partai politik yang memperjuangkannya seperti menjaga Islam sebagai agama (Turmudi, 2000).

Jatuhnya Orde Baru pada Mei 1998 dan dijalankannya demokratisasi serta reformasi oleh pemerintah yang menggantikannya, memunculkan euforia politik sehingga muncul partai-partai baru yang menawarkan poltik tertentu. Dari kalangan NU muncul rencana untuk mendirikan partai baru. Isu tentang pendirian partai baru dari kalangan NU memicu konflik di dalam internal warga NU sendiri termasuk warga nahdliyin di Jepara. Kuatnya pengaruh PPP sebagai partai yang didukung mayoritas warga NU di Jepara dan merupakan kendaraan politik, menjadikan PPP sebagai lambang perjuangan sekaligus perlawanan terhadap pemerintah Orde Baru yang represif.

Kuatnya dukungan masyarakat Jepara terhadap PPP telah ditempa melalui perjalanan sejarah dalam pemilu selama orde baru. PPP di Kabupaten Jepara tidak pernah dikalahkan secara mutlak oleh Golkar sebagai partai yang didukung oleh penguasa orde baru, padahal didaerah lain PPP mudah mengalami kemunduran dalam perolehan suara dalam pemilu yang diakibatkan perpindahan dukungan oleh kalangan NU, mengingat sumber dukungan terbesar PPP berasal dari kalangan NU. Ketika dukungan NU dicabut pada tahun 1983 setelah Muktamar ke-27 di Situbondo Jawa 
Timur yang salah satu keputusannya yaitu NU sebagai ormas menarik diri dari politik praktis dan mengikuti tuntunan asas tunggal pancasila, maka perolehan suara secara nasional PPP pada pemilu 1987 menurun sangat tajam, daari 27\% suara yaang diperoleh pada pemilu 1982 menjadi hanya sekitar $15 \%$ perolehan suara pada pemilu 1987. Ini terjadi karena banyak dari ulama NU ikut menggembosi PPP. Namun di Jepara dalam pemilu 1987 PPP justru mengalami kenaikan yang lumayan. Berikut hasil perolehan suara PPP pada pemilu 1982 hingga pemilu 1997 (Turmudi, 2000).

Tabel 1.

Hasil perolehan suara PPP pada pemilu 1982 hingga pemilu 1997 di Jepara (Turmudi, 2000).

\begin{tabular}{lllll}
\hline Partai & 1982 & 1987 & 1992 & 1997 \\
\hline PPP & 178.573 & 280.841 & 284.083 & 226.564 \\
& $(47,98)$ & $(54,45)$ & $(53,89)$ & $(44,35)$ \\
\hline \multirow{2}{*}{ Golkar } & 179.122 & 218.639 & 206.125 & 276.311 \\
& $(48,13)$ & $(42.39)$ & $(39,10)$ & $(54,09)$ \\
\hline \multirow{2}{*}{ PDI } & 14.490 & 16.273 & 36.964 & 7.924 \\
& $(3,89)$ & $(3,16)$ & $(7,01)$ & $(1,55)$ \\
\hline
\end{tabular}

Dikutip dari: Endang Turmudi, "Reformasi dan Konflik Politik Antar Pendukung Partai Islam, Studi Kasus Jepara", (Turmudi, 2000)

Dari Table 1 dapat diketahui bahwa dukungan warga NU di Jepara terhadap PPP cukup kuat sehingga mampu bersaing dari partai-partai lain. Ini sejalan dengan orientasi politik masyarakat Jepara yang menganggap partai politik yang menjalankan politik Islam wajib didukung dan dibela seperti membela agama Islam sendiri.

Rencana pembentukan partai baru dari kalangan pengurus NU tingkat pusat setelah Orde Baru runtuh membuat PPP di Jepara melakukan berbagai strategi untuk menarik simpati warga NU sebagai sumber dukungan terbesarnya. Isu tentang rencana pembentukan partai baru dari kalangan NU membuat ketegangan yang berujung konflik antara warga NU sendiri. Keberadaan partai baru dari kalangan NU dianggap menyalahi aturan
Muktamar NU ke-27 di Situbondo pada 1983.

Keputusan Muktamar menegaskan NU secara institusional tidak terlibat dalam politik praktis, juga dapat memecah dukungan warga NU terhadap PPP yang selama ini merupakan kendaraan politik warga NU Jepara (Wawancara dengan Maskury Rosyid, 1 September 2015). Terpecahnya dukungan warga NU tehadap PPP dan beralih ke partai yang didirikan dari kalangan NU sendiri menyebabkan konflik yang berujung kerusuhan pada 7 Juli 1998 di kota Jepara. Persaingan politik dalam memperebutkan dukungan dari kalangan warga NU Jepara menyebabkan terpecahnya persatuan dalam masyarakat Jepara dan berujung konflik yang mengambil korban jiwa dan harta benda. 


\section{Merunut Akar Kontestasi}

Kerusuhan 7 Juli 1998 di Jepara disebabkanoleh beberapa faktor yang melatar belakangi timbulnya kerusuhan. Menurut Smelser, suatu gejolak sosial timbul akibat adanya suatu kondisi struktural yang mendukung atau structural conduciviness sehingga memberi kesempatan terbentuknya perilaku kolektif (massa) yang memicu ketegangan dalam masyarakat (Lihat Smelser, 2011). Dalam kasus di Jepara keberadaan seorang pemimpin sangat berperan untuk memobilisasi massa/kelompok masyarakat untuk bertindak sesuai keyakinan yang dibawa oleh pemimpin tersebut dan sangat berpengaruh dalam diri pengikutnya.

Beberapa faktor yang menyebabkan terjadinya kerusuhan di Jepara pada 7 Juli 1998 dapat dijelaskan dibawah ini.

\section{Politisasi Agama}

Kerusuhan 7 Juli 1998 di Jepara merupakan bentuk konflik warga nahdliyin yang bersifat politis. Agama dimanfaatkan oleh partai politik sebagai sarana merekrut dukungan massa Islam. Aktivitas keagamaan seperti pengajian dijadikan sebagai media propaganda dan kampanye partai.

Keberadaan tokoh kyai dalam partai politik semakin memperkuat politisasi agama untuk kepentingan partai politik. Hal ini bisa dilihat dari bahasa agama yang dipakai untuk melegitimasi partai. Misalnya, pernyataan " kalau tidak memilih partai A atau B tidak masuk surga". Politisasi agama menjadi salah satu faktor yang mempengaruhi massa untuk melakukan demonstrasi yang berujung pada kerusuhan (Wawancara dengan Hadi Priyanto, 25 Mei 2015).

Kerusuhan di Jepara terjadi akibat ketidaktahuan massa pendukung terhadap hubungan antara agama dan politik. Masyarakat Islam Jepara selama ini beranggapan bahwa partai Islam yang dianggap memperjuangkan Islam hanya partai yang berasaskan Islam. Akibat kurangnya pendidikan politik yang diterima massa pendukung, akhirnya sesama warga Nahdlatul Ulama (NU) di Jepara saling bermusuhan (Wawancara dengan Hadi Priyanto, 25 Mei 2015).

Masyarakat Jepara sendiri secara realitas kehidupannya sangat terikat dengan agama. Agama dipahami sebagai satu-satunya tolak ukur dalam perilaku sehari-hari. Dalam kondisi seperti itu, agama dijadikan alat oleh elite politik untuk memobilisasi massa. Sentimen-sentimen yang berasal dari agama dijadikan pengikat untuk berbuat seakan-akan "membela Tuhan" atau "ajaran Tuhan", sehingga kekerasan atau kerusuhan seakan-akan dibenarkan dalam agama. Massa juga menggunakan simbol-simbol agama sebagai alat justifikasi perilaku kekerasan (Zazeri, 2007).

Politisasi agama di masyarakat Jepara dilakukan secara sistematis oleh beberapa mubaligh atau kyai dalam pengajiannya. Para kyai yang bersimpati terhadap partai politik tertentu memberi materi ceramah yang berisi ujaran kebencian dan provokasi terhadap massa untuk bertindak radikal terhadap kelompok lain di luar golongannya. Misalnya pernyataan"halal darahnya orang yang mengaku Islam tapi tidak memilih PPP" atau "selain orang PPP kafir." Hal ini menimbulkan kebencian pendukung fanatik PPP terhadap golongan lain termasuk sesama warga nahdliyin yang mendukung partai politik lain (Wawancara dengan Muhammadi Kosim, 22 Mei 2015). Kyai yang isi ceramahnya di anggap "keras" diantaranya Kyai Affifudin dari Semarang dan Kyai Shihabbudin dari Temanggung. Kedua kyai itu merupakan simpatisan dan sekaligus sebagai juru kampanye PPP (Wawancara dengan Ahmad Sholeh, 27 September 2015). 
Kegiatan pengajian dimanfaatkan sebagai sarana untuk mensosialisasikan pandangan kyai. Pengajian yang diadakan oleh masyarakat Jepara dengan mengundang kyai dilakukan secara swadaya. Pengajian yang berlangsung tidak boleh menggunakan fasilitas masjid karena masjid merupakan fasilitas umum. Pengajian biasanya diadakan di rumah warga dalam berbagai acara seperti, haul, khitanan, sedekah membangun rumah, syukuran, pernikahan, dan pengajian rutin lainnya (Wawancara dengan Ali Rosyid, 19 September 2015).

Setelah Orde Baru jatuh pada Mei 1998 aktivitas pengajian semakin gencar dilakukan pihak DPC PPP Jepara. Pengajian dilakukan sebagai sarana konsolidasi pendukung PPP. Hal ini dilakukan untuk mempertahankan suara PPP dari partai yang bermunculan pascareformasi. Pada rapat internal DPC PPP Jepara sepakat untuk mengundang Kyai sebagai juru kampanye. Kyai yang diundang merupakan simpatisan PPP dan yang mampu menarik massa untuk menghadiri ceramahnya. Kyai-kyai yang sering diundang ke Jepara diantaranya $\mathrm{KH}$. Affifudin dari Semarang, $\mathrm{KH}$. Shihabudin dari Temanggung, dan Hj. Arifah dari Demak (Wawancara dengan Abdul Rosyid, 19 September 2015).

Dalam setiap pengajian yang menghadirkan kyai-kyai tersebut selalu ramai didatangi masyarakat, terutama anak-anak muda. Mereka antusias datang karena isi ceramahnya sangat berani dan seringkali membongkar kejelekankejelekan pemerintah Orde Baru, Golkar, dan tokoh NU yang pindah dari PPP dan beralih ke partai lain. Masyarakat tertarik karena dianggap isi ceramah membuka kebenaran yang selama ini mereka tidak tahu. Isi ceramah selalu diselingi dengan ayat-ayat Al-Quran dan hadits sebagai pembenar ucapan kyai (Wawancara dengan Sumarno, 19 September 2015). Pengajian tersebut mampu membakar semangat masyarakat dan membuat PPP semakin kuat di Jepara.

Menurut Affifudin, ceramahnya hanya mengungkapkan kebenaran yang selama ini ditutupi oleh penguasa Orde Baru. Selain itu ia mengkritik tokoh-tokoh NU yang tidak konsisten mendukung PPP dan dianggap sebagai "kutu loncat". Kritik juga diarahkan kepada Gus Dur karena yang semula mendukung PPP kemudian setelah reformasi merencanakan pembentukan partai baru untuk kalangan NU. Ia berpendapat lebih baik jujur dan terbuka dalam menyampaikan ceramahnya agar masyarakat tidak dibodohi. Menurutnya, mengenai kata-kata kasar yang sering dilontarkannya dipandang sebagai ungkapan dan sindiran dan tidak berniat menghasut ataupun memprovokasi masyarakat (Wawancara dengan Affifudin, 10 Maret 2015).

Kyai Affifudin sendiri adalah seorang Kyai dan pengasuh pondok pesanten di Semarang, ia merupakan simpatisan PPP namun tidak terlibat dalam kepengurusan partai. Pada rentang tahun 1997-1999 ia sering diundang untuk berceramah sekaligus sebagai juru kampanye PPP. Pengikutnya tersebar di sepanjang Pantura terutama Pekalongan, Kendal, Semarang, Demak, Jepara dan Kudus. Pada tahun 1997 ia dikaitkan sebagai provokator kerusuhan di Buaran Pekalongan (Nurdiyanto, 2004). Namun pihak keamanan tidak memiliki bukti untuk menahannya.

Menurut Arifah, isi ceramah yang disampaikannya disesuaikan dengan acara pengajian, namun ia menyelipkan pendidikan politik dengan tujuan agar masyarakat Islam dapat menyalurkan aspirasi politiknya ke partai yang benarbenar memperjuangkan Islam dalam hal ini PPP. Ia menyampaikan ceramahnya apa adanya seperti realitas yang terjadi di masyarakat. Menurutnya, kebenaran tidak perlu ditutupi seperti yang

\begin{tabular}{l|l} 
Jurnal Multikultural \& Multireligius Vol. 19 & No. 2
\end{tabular} 
terjadi di masa Orde Baru karena hal tersebut membuat umat Islam terbodohi (Wawancara dengan Siti Arifah, 26 September 2015). Hj. Arifah merupakan seorang penceramah wanita yang sering di undang di pengajian-pengajian di Kabupaten Jepara. Oleh sebagian masyarakat Jepara isi ceramahnya terlalu "Berani" dalam menyampaikan kebenaran. Ia juga merupakan simpatisan sekaligus juru kampanye PPP.

Kegiatan pengajian dijadikan sarana untuk media sosialisasi politik bagi PPP. Dalam setiap pengajian yang diadakan, hadir beberapa kyai lokal sebagai tuan rumah, pengurus cabang PPP dan beragam atribut PPP. Sebagian masyarakat Islam Jepara menganggap tidak lengkap jika suatu acara pengajian tanpa hadirnya PPP sebagai wadah pemersatu dan penyalur aspirasi umat Islam (Wawancara dengan Thoha Makmum, 26 September 2015).

Menurut Thoha Makmum, politik tidak dapat dilepaskan dari agama. Ia mencontohkan, Nabi Muhammad SAW menggunakan politik dalam perjuangan Islam. Dalam setiap ceramahnya ia seringkali mengutip beberapa hadist yang menerangkan perjuangan Islam melalui politik. Menurutnya PPP merupakan partai yang mencerminkan kendaraan politik Islam. Ia mencontohkan pendirian PPP merupakan hasil keikhlasan dari para pemimpin partai Islam untuk menyatukan suara umat Islam (Wawancara dengan Thoha Makmum, 26 September 2015). Thoha Makmum sendiri merupakan seorang Kyai pengasuh Pondok Pesantren di Desa Bugel Kecamatan Kedung Kabupaten Jepara. Ia merupakan simpatisan PPP yang cukup berpengaruh di Kabupaten Jepara. Dalam setiap cermahnya ia selalu menekankan pentingnya politik dalam perjuangan Islam. PPP menurutnya merupakan satusatunya partai yang mampu menyurakan suara umat islam di Indonesia.

\section{Keterlibatan Kyai dalam Politik}

Keberadaan kyai dan politik adalah entitas yang tak terpisahkan dalam konstelasi politik Indonesia. Kyai telah diakui oleh orang Indonesia atas kontribusinya di bidang keagamaan dan politik (Syamsuddin, 2013).

Posisi kyai di Jepara dipandang istimewa dan dianggap sebagai pewaris Nabi. Para santri menerima kepemimpinan kyai karena mempercayai konsep barokah (Muhtadi, 2004). Persepsi tersebut berkembang dimasyarakat dan kemudian menjadi tali pengikat antara kyai, santri dan masyarakat. Pengaruh tersebut kemudian membawa sikap tersendiri di kalangan masyarakat, seperti penghormatan dan kepatuhan akan perintah dan anjuran dari seorang kyai. Dengan kata lain setiap anjuran perlu diikuti.

Merujuk pendapat Endang Turmudi, kyai dibedakan menjasi empat tipologi. Pertama, Kyai pesantren, yakni mereka yang memusatkan perhatiannya pada pengajaran di pesantren. Kedua, Kyai tarekat, yakni mereka yang memusatkan perhatiannya dalam membangun kecerdasan batin umat Islam. Ketiga, Kyai politik, yaitu mereka yang mempunyai perhatian untuk mengembangkan NU dan terlibat politik praktis. Keempat, Kyai panggung, yaitu mereka yang menjadi juru dakwah (Muballigh) yang hampir setiap hari menyampaikan ceramah agama di berbagai tempat. (Turmudi; Moesa, 2007).

Tipe kepemimpinan kyai di Jepara menempatkan kyai atau ulama sebagai patron dan kalangan santri, dan masyarakat sebagai klien-nya. Pola hubungan kyai dalam masyarakat Jepara ditentukan oleh kekuatan kharisma seorang kyai. Seorang kyai bertindak sebagai patron untuk memecahkan berbagai persoalan kehidupan yang berkaitan dengan agama, sosial, ekonomi dan politik (Sahidin, 2001). Di 
sisi lain masyarakat atau pengikut kyai bersedia melakukan aksi apa saja demi menjaga kharisma kyai sebagai bentuk pengabdian. Keterlibatan kyai di Jepara dalam dunia politik turut mempengaruhi pandangan politik pengikutnya (santri) dalam menentukaan orientasi politiknya. Akibat kondisi tersebut partai-partai politik menjadikan sosok kyai sebagai penarik dukungan massa terutama para pengikutnya.

Keterlibatan kyai dalam politik di Jepara terjadi karena tokoh-tokoh partai kurang percaya diri dalam mengenalkan dan mensosialisasikan partainya. Keberadaan kyai dianggap mampu menarik masyarakat untuk mendukung partai politik yang didukung tokoh kyai. Kyai dalam struktur kepartaian di Jepara misalnya dalam hal ini PPP, menempati posisi sebagai penasehat atau majelis pertimbangan. Kyai selalu dimintai pendapatnya dalam menentukan arah kebijakan partai bahkan juga dalam memilih calon yang akan diajukan dalam pemilu (Wawancara dengan Thoha Makmum dan Ahmad Sholeh, 26 September 2015).

Kyai di Jepara sebagian besar merupakan simpatisan maupun anggota dari partai politik (Wawancara dengan Thoha Makmum, 26 September 2015). Posisi kyai di tengah-tengah masyarakat dimanfaatkan oleh partai politik untuk menarik dukungan dari pengikut dan santrinya. Sebagai contoh $\mathrm{KH}$. Muhammadi Kosim yang merupakan ketua cabang NU periode 1969-1998 merupakan pendukung sekaligus pengurus PPP Jepara. Menjelang terjadinya peristiwa kerusuhan di Jepara, dia terlibat dalam rencana pembentukan partai baru dari kalangan NU. Keadaan tersebut menimbulkan gesekan dengan warga NU yang mendukung PPP (Wawancara dengan Abdul Rosyid, 19 September 2015). Jika kyai mendukung partai politik tertentu maka secara tidak langsung, kyai membawa massa pengikutnya. Oleh karena itu PPP Jepara menggunakan strategi dengan mengundang kyai yang memiliki pengikut dan kharisma lebih besar dari kyai lokal.

Keterlibatan kyai dalam politik tidak terlepas dari NU sebagai organisasi kyai. Sebagian besar kyai terjun dalam dunia politik karena mengikuti kyai yang lebih besar yang menjadi panutannya. Namun ada sebagian kyai yang hanya ikut-ikutan dalam berpolitik (Wawancara dengan Abdul Rosyid, 19 September 2015). Sebagai contoh, misalnya Kyai Thoha Makmum pengasuh Pondok Pesantren Al-Makmum Bugel Kecamatan Pecangaan Jepara, Ia terjun dalam dunia politik karena mengikuti Kyai panutannya yaitu K.H. Maemun Zubaer pengasuh Pondok Pesantren Al-Anwar, Sarang, Rembang Jawa Timur. K.H Maemun Zubaer adalah Kyai sepuh pendukung PPP (Wawancara dengan Thoha Makmum, 26 September 2015).

\section{Perebutan Pengaruh}

Kesamaan basis massa yang digarap oleh beberapa partai politik serta kedekatan ideologi antar partai yang ada dapat dipastikan bahwa partai-partai yang memiliki ideologi yang sama akan berebut pangsa pasar yang sama (Zazeri, 2007). Kerusuhan 7 Juli 1998 di Jepara terjadi karena adanya perebutan pengaruh PPP dengan partai yang akan didirikan oleh tokoh-tokoh NU. Antara PPP dengan embrio partai NU mempunyai basis massa yang sama yaitu NU.Kerusuhan 7 Juli 1997 merupakan puncak perebutan pengaruh para elite politik PPP dan tokoh-tokoh NU Jepara yang mendukung terbentuknya partai baru dari kalangan NU sendiri. Kerusuhan terjadi bukan hanya karena adanya isu pelarangan ceramah kyai PPP yang provokatif di Jepara namun karena persoalan perebutan 
pengaruh warga nahdliyin. Tokoh-tokoh kyai yang bersimpati terhadap PPP dan terkenal dengan ceramah yang berapiapi dan bersifat provokatif semakin gencar mengisi ceramah di Jepara setelah munculnya isu akan adanya rencana pembentukan partai baru dari kalangan NU. Kondisi tersebut membuat pengurus PPP khawatir suara dari kalangan warga NU akan pindah ke partai baru yang akan didirikan oleh pengurus NU (Wawancara dengan Muhammadi Kosim, 22 Mei 2015).

Salah satu tokoh kyai yang sering diundang untuk mengisi ceramah di Jepara yaitu Kyai Affifudin dari Semarang. Kyai Affifudin ceramah di berbagai acara mulai dari sunatan, syukuran, haul, pernikahan dan lain-lain. Setiap acara yang diisi oleh Kyai Affifudin selalu penuh oleh jamaah terutama kalangan anak muda (Wawancara dengan Sumarno, 19 September 2015). Isi ceramah yang dibawakannya blak-blakan dan memprovokasi golongan lain. Bahkan mendiskreditkan pemerintah dan pejabat baik daerah maupun pusat. Substansi ceramahnya cenderung berisi ujaran kebencian (hate speech)(Ahnaf \& Suhadi, 2014), menghasut dan memancing SARA dengan perkataan "Pejabat yang tidak mendukung PPP adalah kafir, Yahudi dan mendukung Kristenisasi", "Kyai atau ulama NU yang mendukung partai lain disebut kyai celeng (babi hutan), kyai asu (anjing) dan "halal darah orang yang tidak mendukung PPP" (Wawancara dengan Harsono, 20 Maret 2015).

\section{Munculnya Gerakan Anti-Affifudin}

Kehadiran Kyai Affifudin dan kyai-kyai lainnya yang dianggap "keras" pada awalnya bertujuan sebagai media menarik massa pendukung PPP. Namun sebagian masyarakat Jepara ada yang tidak menyukai kehadiran kyai tersebut. Penolakan terhadap kehadiran Kyai Affifudin tidak hanya muncul dari kalangan rakyat biasa namun juga muncul dari kalangan elite pemerintahan dan para kyai lokal. Hal ini karena ceramah yang dibawakan Kyai Affudin seringkali disisipi perkataan jorok seperti asu, celeng, kirik terutama kalau membicarakan masalah Soeharto, Golkar dan aparat pemerintah. Bahkan para kyai yang tidak mendukung PPP juga dianggap bisa merusak citra seorang kyai sebagai tokoh agama (Wawancara dengan Mahbub Junaidi, 22 Mei 2015).

Munculnya gerakan penolakan kehadiran kyai-kyai yang dianggap keras dipelopori oleh Kepala Desa Tegal Sambi Kecamatan Tahunan, Jepara, Nurkhamid. Dia menghimpun masyarakat dan tokohtokoh yang menolak kehadiran kyai tersebut di Jepara. Nurkhamid mendekati anggota-anggota Partai Golkar terutama para pejabat pemerintahan di Kecamatan Tahunan. Selain itu dia menghimpun dukungan terhadap kyai-kyai lokal yang bukan pendukung PPP di kecamatan Tahunan untuk mengadakan gerakan anti-Affifudin (Wawancara dengan Harsono, 20 Maret 2015).

Koordinasi gerakan dilakukan melalui rapat-rapat kecil di rumah warga. Seluruh kepala desa di kecamatan Tahunan mendukung gerakan tersebut. Tujuan gerakan tersebut agar kyaikyai yang ceramahnya berisi provokasi dilarang hadir di pengajian di wilayah Jepara. Kyai yang provokatif dianggap mengganggu stabilitas masyarakat.

Gerakan penolakan masyarakat diberi nama gerakan anti-Affifudin. Rencana penolakan disuarakan melalui aksi demonstrasi ke DPRD Kabupaten Jepara. Aksi demontrasi dilaksanakan pada tanggal 1 Juli 1998. Aksi demontrasi diikuti oleh sekitar 150 orang yang terdiri dari 15 kepala desa, tokoh masyarakat, pemuda, masyarakat umum, dan beberapa kyai yang menolak kehadiran Affifudin. Pengamanan aksi diserahkan pada Harsono yang merupakan 
petugas seksi keamanan dan ketertiban Kecamatan Tahunan (Wawancara dengan Harsono, 20 Maret 2015).

Kehadiran demonstran diterima oleh anggota DPRD Jepara. Perwakilan demonstran diundang masuk ke kantor DPRDuntukmenyampaikan tuntutannya. Tuntutan yang disampaikan demonstran yaitu menolak kehadiran Kyai Affifudin, Kyai Shihabudin, dan $\mathrm{Hj}$. Arifah yang akan diadakan di Jepara (Suara Merdeka, 8 Juli 1998). Namun tuntutan demonstran ditolak oleh ketua DPC PPP Maskyuri Rosyid, yang juga merupakan wakil ketua DPRD. Menurut Maskyuri tidak boleh ada larangan berceramah terhadap Kyai tertentu karena dapat menimbulkan sentimen keagamaan. Lebih-lebih kyaikyai tersebut memilikibanyak pendukung di Jepara (Wawancara dengan Maskury Rosyid, 1 September 2015).

Dalam aksi tersebut keadaan berubah tegang karena massa demonstran di luar gedung DPRD menganiaya dan mengancam Korcam PPP kecamatan Tahunan yang bernama Solikhin. Sholikhin sendiri merupakan Koordinator PPP Kecamatan Tahunan, Ia yang mengatur setiap aktivitas pengajian yang diadakan PPP (Wawancara dengan Maskury Rosyid, 1 September 2015).

Akhirnya tuntutan demonstran dipenuhi oleh Fraksi PPP di DPRD Jepara. Fraksi PPP dipimpin Maskury Rosyid membuat surat pernyataan yang berisi larangan pengajian yang menghadirkan kyai tersebut. Setelah tuntutan dipenuhi, para demonstran membubarkan diri (Wawancara dengan Abdul Rosyid, 19 September 2015).

\section{Muncul Isu di Masyarakat Jepara}

Setelah demonstrasi 1 Juli 1998 di DPRD Jepara oleh kelompok yang menolak kehadiran Kyai Affifudin, muncul berbagai isu di masyarakat.
Salah satu isunya adalah pelarangan Kyai Affifudin berceramah di Jepara oleh Bupati dengan menyuruh kepala desa di kecamatan Tahunan untuk menolak kehadiran kyai tersebut (Wawancara dengan Hadi Priyanto, 25 Mei 2015). Isu pelarangan dan adanya unjuk rasa penolakan kehadiran Kyai Affifudin tersebar luas di masyarakat, baik melalui media pengajian dan mulut ke mulut, bahkan dari siaran radio ilegal yang sering menyiarkan ceramah Kyai Affifudin dan kyai lainnya.

Isu tersebut segera dibantah oleh Bupati Jepara Drs. Soenarto. Untuk menjernihkan suasana, Bupati membuat surat pernyataan No. 451.1/02988 tertanggal 4 Juli 1998 yang berisi bahwa pemerintah tidak melakukan pelarangan ceramah para kyai tersebut (Republika, 9 Juli 1998).

Di lain pihak DPC PPP berencana mengadakan unjuk rasa. Rencana unjuk rasa ditentukan tanggal 7 Juli 1998. Unjuk rasa yang dilakukan sebagai reaksi terhadap demonstrasi 1 Juli 1998 oleh kelompok yang menolak kehadiran Kyai Afifudin dan kyai lainnya. Rencana unjuk rasa tandingan diadakan pada hari Selasa 7 Juli 1998. Namun rencana tersebut dibatalkan oleh DPC PPP setelah rapat pada 4 Juli 1998 dengan Bupati Jepara, Soenarto (Suara Merdeka, 8 Juli 1998). Pengumuman pembatalan aksi demonstrasi tandingan tersebut ditandatangani langsung oleh ketua DPC PPP Jepara, Maskyuri Rosyid (Wawancara dengan Abdul Rosyid, 19 September 2015).

Pembatalan aksi demonstrasi tandingan oleh DPC PPP dan surat pernyataan dari Bupati Jepara tidak tersebar luas di masyarakat. Masyarakat sudah terlanjur mendapat informasi mengenai unjukrasa yang akan dilaksanakan pada hari selasa 7 Juli 1998. Isu-isu tentang pelarangan ceramah semakin santer (Wawancara dengan 
Pramudyi, 21 Mei 2015). Isu pelarangan tersebut menyebar hingga Semarang, Demak, dan Kendal yang merupakan basis massa kyai tersebut.

Selain itu masyarakat juga menerima informasi tentang akan ada pengajian besar di alun-alun Jepara pada 7 Juli 1998 yang dihadiri oleh Kyai Affifudin (Wawancara dengan Darsono, 20 Maret 2015). Meskipun masih simpang siur dan tidak jelas kebenarannya informasi tersebut. Disisi lain masyarakat terlanjur percaya bahwa Bupati Soenarto dan aparat pemerintah terlibat dalam pelaranganceramah.Sebagian masyarakat menganggap adanya pelarangan ceramah merupakan tindakan pelecehan terhadap agama Islam dan menghambat dakwah Islam. Kepemimpinan Bupati Soenarto sendiri di Jepara kurang disukai sebagian masyarakat, karena ia bersikap keras dan diskriminatif terhadap golongan lain, termasuk PPP (Wawancara dengan Abdul Rosyid dan diperkuat dengan wawancara Sumarno dan Ali Rosyid, 19 September 2015).

\section{Jalannya Aksi Kerusuhan 7 Juli 1998}

Aksi demonstrasi para pengikut Kyai Affifudin dilakukan pada 7 Juli 1998. Pada hari tersebut sekitar pukul 09.00 massa mulai berdatangan dan bergerak ke satu arah, yakni Gedung DPRD. Massa datang dari wilayah Jepara, Demak, Kudus dan Pati bahkan dari Semarang (Wawancara dengan Abdul Rosyid, 19 September 2015). Massa datang menggunakan puluhan truk, bahkan ada yang datang dari arah laut menggunakan perahu. Massa yang menggunakan perahu mendarat di pelabuhan Kartini, diduga massa ini diyakini datang dari Semarang dan Demak. Selain itu massa yang datang ke DPRD ada yang berjalan kaki (Wawancara dengan Pramudyi, 21 Mei 2015). Jumlah massa demonstrasi yang berdatangan sekitar 6000 orang (Pikiran
Rakyat, 9 juli 1998). Massa membawa poster yang isinya mendukung kehadiran Kyai Affifudin di seluruh wilayah Jepara dan menolak adanya pelarangan ceramah (Wawancara dengan Suprianto, 21 Mei 2015). Sebagian besar massa yang membawa atribut PPP. Sebagian besar massa yang hadir merupakan pendukung Kyai Affifudin dan juga simpatisan PPP, jadi cukup wajar jika dalam aksi tersebut atribut PPP digunakan (Wawancara dengan Abdul Rosyid, 19 September 2015).

Massa hadir atas inisiatif sendiri. Saat demonstrasi berlangsung tidak terlihat adanya koordinator massa (Wawancara dengan Muhammadi Kosim pada 22 Mei 2015 dan diperkuat oleh wawancara dengan Abdul Rosyid dan Pramudyi pada 19September 2015). Massa berkumpul di DPRD Jepara kemudian diterima dan berusaha ditenangkan oleh pimpinan DPRD dan Kapolres Jepara Letkol Pol Monang Manulang. Mereka menegaskan bahwa tidak ada pelarangan kyai tersebut tampil dalam pengajian di wilayah Jepara. Akan tetapi massa belum puas dan bergerak ke pendopo kabupaten. Di alun-alun depan kantor bupati, massa meneriakkan tuduhan bahwa Bupati Soenarto dianggap yang menyuruh Kepala Desa Nurkhamid dan Harsono yang kemudian memunculkan demo pelarangan Affifudin di DPRD. Massa juga menuntut agar bupati mencopot Nurkhamid dan Harsono dari Jabatannya (Kompas, 8 Juli 1998).

Ketika demontran sedang berorasi di depan DPRD Jepara, di tengah kerumunan massa muncul isu, adanya demonstran yang diamankan petugas di Gedung Korpri (Wawancara dengan Abdul Rosyid pada 19 September 2015 dan diperkuat dengan hasil wawacara dengan Hadi Priyanto pada 25 Mei 2015). Akibat isu tersebut, massa mulai bertindak anarkis dengan melempari gedung bupati dengan batu. Di tengah-tengah tindakan 
anarkis tersebut terdengar teriakan "bakar-bakar" dan pekik takbir. Massa kemudian mendobrak pintu pagar kantor bupati yang telah dikunci sebelumnya (Wawancara dengan Hadi Priyanto, 25 Mei 2015). Akhirnya massa dapat masuk ke halaman kantor dan membakar Gedung Korpri, gedung perpustakaan, dan kendaraan yang diparkir di dekat gedung. Pegawai kantor bupati lari melalui pintu belakang gedung yang mengarah ke perkampungan penduduk (Wawancara dengan Darsono, 20 Maret 2015). Sedangkan bupati tidak ada di kantor dan baru melihat kondisi kantor pada sore hari (Suara Merdeka, 8 Juli 1998).

Dari kabupaten, sebagian massa bergerak ke arah Desa Tegal Sambi tempat tinggal Kepala Desa Nurkhamid. Massa menyuruh Nurkhamid keluar, namun Nurkhamid beserta keluarga berhasil menyelamatkan diri ke ladang belakang rumahnya. Massa yang tidak menemui Nurkhamid kemudian mengeluarkan isi rumah dan membakarnya. Warga Desa Tegal Sambi tidak berani keluar rumah dan sebagian besar masyarakat berada di ladang sehingga massa leluasa melakukan aksinya (Wawancara dengan Harsono, 20 Maret 2015). Warga Tegal Sambi sepakat tidak melakukan perlawanan karena dikhawatirkan jatuh korban Jiwa. Aparat keamanan juga tidak terlihat di lokasi. (Wawacara dengan Sumarno, 19 September 2015).

Massa di alun-alun juga bergerak ke arah pertokoan Pecinan di Jalan Diponegoro, 200 meter dari alunalun. Massa melakukan pengrusakan, pembakaran serta menjarah isi toko. Toko yang rusak dan dijarah sebanyak 31 toko dan yang dibakar sebanyak 6 toko. Adapun toko Swalayan Saudara yang merupakan toko terbesar mengalami kerusakan pada pintu dan kaca-kaca. Hotel Kalingga dan Hotel Samudra mengalami kerusakan ringan. Massa kemudian berbelok ke jalan Sugiono dan membakar satu toko peralatan nelayan. Rambu-rambu lalu lintas dan pot-pot bunga di sepanjang jalan tidak luput dari aksi pengrusakan massa (Suara Merdeka, 9 juli 1998). Namun para pemilik toko telah menyelamatkan diri ketika amuk massa terjadi karena telah diinformasikan oleh Supriyanto, Lurah Jebokuto Kota Jepara. Atas inisiatif sendiri, Suprianto dibantu aparat kelurahan menyebarkan informasi melalui pengeras suara di masjid agar masyarakat segera menyelamatkan diri dari amuk massa. Sebagian besar warga Kelurahan Jebokuto merupakan keturunan etnis Tionghoa dan membuka usaha dengan berdagang di sepanjang jalan Diponegoro (Wawancara dengan Suprianto, 21 Mei 2015).

Pada saat kejadian, aparat keamanan yang bertugas berjumlah 18 orang polisi yang dibagi 2 regu, 1 regu bertugas mengamankan kawasan pecinan (Jalan Diponegoro) dan 1 regu bertugas mengamankan kantor bupati (Suara Merdeka, 8 juli 1998). Jumlah Aparat yang sedikit tidak sebanding dengan jumlah pengunjuk rasa, sehingga membuat petugas tidak dapat berbuat apa-apa ketika kerusuhan berlangsung. Aparat tidak melakukan tindakan apaapa kecuali pengamanan obyek vital (Wawancara dengan Hadi Priyanto, 25 Mei 2015). Setelah pukul 14.00 aparat gabungan dari Brimob dengan jumlah 1 SSK, 1 SST Batalion 410, 2 SST Kodim dan SSK Arhanud diturunkan untuk menenangkan massa yang anarkis. Aparat yang didatangkan dari Semarang dan Pati, akhirnya berhasil menguasai Kota Jepara menjelang sore harinya dan para pengunjuk rasa membubarkan diri pada pukul 16.00 dengan konvoi keliling kota dan kembali ke tempat masing-masing.

Ketika kerusuhan berlangsung, pimpinan DPC PPP beserta Kapolres berada di lokasi kejadian namun tak mampu menghadapi amarah massa yang tidak terkendali. Aparat tidak berani 
menghalau massa karena jumlahnya yang tidak sebanding. Dalam kondisi yang semakin memanas, tokoh NU Jepara didatangkan untuk menenangkan massa. Ketua cabang NU Jepara Muhammadi Kosim diundang untuk menenangkan massa yang rata-rata adalah warga NU. Muhammadi meminjam mikrofon Masjid Baitul Makmur (dekat kantor Bupati) dengan membaca istighfar dan menyerukan agar warga NU pulang ke rumah dan shalat zuhur. Sebagian massa menuruti anjuran tersebut dan mulai membubarkan diri (Wawancara dengan Muhammadi Kosim, 22 Mei 2015).

Pada saat kejadian Kyai Affifudin juga hadir ke lokasi kerusuhan. Kehadiran dia diundang oleh salah satu anggota PPP Jepara untuk menenangkan massa. Kyai Affifudin tiba di Jepara pukul 14.00. Ia berusaha menghimbau agar massa tidak berbuat anarkis dan meminta massa membubarkan diri (Wawancara dengan Affifudin, 10 Maret 2015). Keadaan Jepara mulai kondusif menjelang petang hari.

Aksi demonstrasi yang berujung kerusuhan di Jepara tidak hanya sematamata memprotes pelarangan ceramah Kyai Affifudin, namun merupakan puncak dari konflik yang telah ada sebelumnya yaitu persaingan politik antar warga NU. Dalam kerusuhan tersebut terlihat peran dari tokoh elite NU dan PPP yang ikut terlibat secara langsung maupun tidak dalam memobilisasi massa. Aparat pemerintah terutama pihak keamanan sebenarnya telah mengetahui akan ada gerakan massa pada tanggal 7 Juli 1998 (Wawancara dengan Pramudyi, 21 Mei 2015).

Menurut kesaksian Pramudyi, Kasi ketertiban umum Dinas Sosial Politik Kabupaten Jepara, ia telah melaporkan ke bupati dan aparat mengenai adanya isu untuk memobilisasi massa pada pengajian-pengajian di wilayah Kecamatan Mlonggo. Namun laporannya tidak ditanggapi dengan serius oleh aparat keamanan. Akibatnya ketika terjadi aksi massa pada 7 Juli 1998 aparat tidak siap dalam menghadapi ribuan massa demonstrasi (Suara Merdeka, 9 Juli 1998).

\section{Akibat Kerusuhan}

Aksi Demonstrasi yang berujung kerusuhan pada 7 Juli 1998 di Jepara tujuan awalnya memprotes demonstrasi pada 1 Juli 1998, tentang penolakan Kyai Affifudin. Namun aksi demonstrasi dimanfaatkan segelintir oknum untuk melakukan penjarahan, pembakaran dan tindakan kekerasan lainnya. Adanya provokator kerusuhan membuat kondisi Jepara tidak kondusif. Akibat kerusuhan tersebut menimbulkan berbagai kerusakan fisik dan dampak pada kehidupan masyarakat Jepara. Berikut ini adalah beberapa dampak yang ditimbulkan dari kerusuhan 7 juli 1998 di Jepara.

\section{Akibat Fisik}

Aksi demonstrasi yang memprotes larangan penyelenggaraan pengajian Kyai Affifudin berubah menjadi kerusuhan. Dampak dari kerusuhan yaitu kerusakan pada kaca-kaca digedung kantor bupati. Pada aksi tersebut massamelempar batu, massa juga membakar gedung Korpri dan gedung perpustakaan. Tidak hanya gedung perkantoran yang menjadi sasaran amuk massa namun massa juga membakar sebuah mobil dinas Kijang milik staf bagian tata pemerintahan ikut dibakar massa, mobil Carry Futura milik Kabag TP Teguh Suporbo ringsek, sebuah mobil yang terparkir di depan Hotel Kalingga, enam sepeda motor dinas, serta dua motor milik pribadi juga ikut dibakar massa (Suara Merdeka, 9 Juli 1998).

Selain itu kamera tustel milik karyawan bagian humas pemda dan petugas polres yang digunakan untuk mengabadikan tindakan anarkis 
dibanting massa hingga hancur. Massa melampiaskan amarah dengan merusak dan membakar beberapa toko di Jalan Diponegoro. Sebagian massa menjarah isi toko. Tercatat sekitar 31 toko mengalami kerusakan dan 6 di antaranya dibakar hingga habis. Toko-toko tersebut merupakan milik warga keturunan Tionghoa yang biasa menjual peralatan elektronik, mebel, sepatu dan sembako. Selain itu massayang bergerak ke Jalan Kolonel Sugiono merusak toko peralatan nelayan dan membakar barang dagangan di jalanan. Satu sepada motor milik Toko Pojok ikut dibakar massa. Sedangkan kaca Hotel Kalingga dan Hotel Samudra hanya rusak ringan akibat lemparan batu. Satu unit ATM BCA yang berada di depan Swalayan Saudara tidak luput dari sasaran amuk massa. Puluhan pot bunga dan rambu lalu lintas ikut dirusak massa hingga mengalami kerusakan cukup parah (Wawancara dengan Suprianto, 21 Mei 2015).

Rumah Kepala Desa Tegal Sambi, Nurkhamid ikut dirusak massa dan isi rumah dibakar. Nurkhamid dianggap sebagi dalang unjuk rasa penolakan Kyai Affifudin pada 1 Juli 1998 di DPRD (Wawancara dengan Mahbub Junaidi, 22 Mei 2015).

Selain kerusakan materi dan fisik, dalam demonstrasi tersebut terdapat korban luka-luka karena bentrok dengan aparat yang menjaga gedung bupati. Dua aparat kepolisian dan seorang demonstran mengalami luka yang cukup serius, yaitu Kapten Pol I Ketut Oni (Kabag Samapta Polwil Pati) dan Kapten Pol Yusron (Kanit Laka Polwil Pati) serta Bambang (Simpatisan PPP), warga Desa Kali Pucang, Kecamatan Welahan Jepara (Suara Merdeka, 8 Juli 1998).

Dampak kerusakan fisik, materi dan korban luka-luka akibat merugikan bagi masyarakat Jepara pada umumnya. Masyarakat yang tidak tahu-menahu ikut menjadi sasaran kerusuhan.

\section{Pengaruh Terhadap Psikologis Masyarakat}

Dampak psikis yang dialami masyarakat setempat terutama yang menjadi korban kerusuhan adalah trauma dan ketakutan. Ketakutan kalau ada kerusuhan susulan, karena sempat berhembus akan terjadi kerusuhan lagi di Jepara (Suara Merdeka, 11 Juli 1998). Meskipun sudah ada jaminan keamanan dari pihak aparat.

Kerusuhan pada 7 Juli 1998 membuat masyarakat Jepara khawatir akan terjadi kerusuhan yang lebih besar. Selama beberapa pekan sejak kerusuhan berlangsung, sebagian penduduk Jepara masih dilanda rasa ketakutan. Banyak warga yang memiliki usaha yang dekat dengan lokasi kerusuhan memilih menutup usahanya sampai benarbenar pulih kondisi keamanan di Jepara (Wawancara dengan Pramudyi, 21 Mei 2015). Kota Jepara selama seminggu seperti kota mati karena masyarakat lebih memilih berdiam di dalam rumah (Wawancara dengan Abdul Rosyid, 19 September 2015).

Trauma dan ketakutan juga dialami oleh para pengusaha dan para pedagang dipasar Kota Jepara, serta warga keturunan etnis Tionghoa. Mereka takut jika kerusuhan meluas seperti di daerah lain di Indonesia pasca Orde Baru runtuh pada Mei 1998. Banyak warga keturunan hingga beberapa hari belum mau pulang dari mengungsi ke sanak saudara karena trauma.

\section{Hubungan Sosial Masyarakat}

Kondisihubungansosialmasyarakat Jepara yang santun dan religius mendadak hancur. Masyarakat menjadi saling curiga satu sama lain, terutama masyarakat yang pro dan kontra terhadap kehadiran Kyai Affifudin. Antara warga NU yang mendukung PPP dengan warga NU yang memilih partai lain terutama yang akan didirikan oleh para tokoh NU

\begin{tabular}{l|l} 
Jurnal Multikultural \& Multireligius Vol. 19 & No. 2
\end{tabular} 
pusat. Menurut Muhammadi Kosim, masyarakat Jepara seperti sumbu pendek yang mudah meledak jika tersulut. akibat dari persaingan antar warga NU yang berbeda pandangan mengenai partai politik. Muhammadi Kosim sendiri merupakan tokoh PPP sebelum tahun 1998 dan sempat menjadi aggota DPRD dari Fraksi PPP periode 1977-1997 dan ketika kerusuhan terjadi beliau menjabat ketua cabang NU Jepara, namun setelah PKB berdiri beliau ikut mempelopori pendirian PKB di kabupaten Jepara (Wawancara dengan Muhammadi Kosim, 22 Mei 2015).

Setelah kerusuhan 7 Juli 1998 didalam masyarakat Jepara muncul semacam kelompok-kelompok keamanan atau satgas sendiri berdasarkan golongan politik. Misalnya, PPP menggagas satgas bernama Nursodo, Shiworogo, Pesat, Pasir Putih, Laskar Ababil, Watu Olet, dan Sadigo (Wawancara dengan Hadi Priyanto, 25 Mei 2015). Setelah PKB resmi berdiri di Kabupaten Jepara pada 23 Juli 1998 muncul kelompok yang diberi nama laskar Balaba (Barisan Bela Bangsa) yang merupakan satgas keamanan dari PKB (Wawancara dengan Mahbub Junaidi, 22 Mei 2015). Kemunculan kelompokkelompok pengaman yang berasal dari partai politik semakin memperkeruh suasana Jepara selama kurun waktu 19981999. Masyarakat dilanda rasa takut jika menjadi sasaran kelompok-kelompok yang saling bertikai tersebut walau paham keagamaan mereka sama yaitu sama-sama penganut paham ahlulsunnah wal jamaah.

\section{Strategi Membangun Rekonsiliasi Pasca Konflik}

Konflik merupakan aspek intrinsik dan tidak mungkin dihindarkan dalam perubahan sosial. Konflik adalah sebuah ekspresi heterogenitas kepentingan, nilai dan kenyataan yang muncul sebagai formasi baru yang ditimbulkan oleh perubahan sosial yang muncul bertentangan dengan hambatan yang diwariskan (Miall, 2000). Konflik sosial di masyarakat seharusnya dapat diatasi dan dicarikan jalan keluarnya, apabila pemerintah yang merupakan pihak yang memiliki kemampuan kontrol sosial mampu menjalankan fungsinya dengan baik. Namun kondisi tersebut tidak terjadi di masayarakat Jepara. Kondisi di Jepara adalah hilangnya kepercayaan masyarakat terhadap pemerintah dan institusinya.Hal tersebut terjadi akibat kebijakan politik diskriminatif yang dijalankan Orde Baru sehingga membuat masyarakat menjadi apatis terhadap pemerintah.

Penanganan yang dilakukan
adalah pertama, pasca terjadinya kerusuhan aparat pemerintah yang terdiri dari kepolisian dan TNI serta tokoh PPP, Tokoh NU, Muhammadiyah, Gereja dan DPRD Jepara yang difasilitasi Bupati Jepara melakukan dialog pada hari Rabu, 9 Juli 1998 untuk membicarakan agar kerusuhan yang terjadi sehari sebelumnya tidak terulang kembali (Suara Merdeka, 9 juli 1998). Namun dialog tersebut hanya berlangsung pada tingkat elite dan bersifat formalitas. Masyarakat sama sekali tidak terefleksikan terhadap hasil dialog tersebut, konflik dan kekerasan masih terus terjadi di Jepara hingga tahun 1999 (Wawancara dengan Abdul Rosyid, 19 September 2015).

Kedua, upaya penanganan pasca kerusuhan terus dilakukan oleh pihak kepolisian melalui pendekatan terhadap Kyai Affififdin yang dalam kasus kerusuhan 7 juli 1998 merupakan pihak yang paling berpengaruh. Pada tanggal 10 Juli 1998, Kyai Affifudin dipanggil Kapolda Jawa Tengah untuk membicarakan solusi dan jalan keluar mengenai kerusuhan di Jepara. Pihak TNI juga memerintahkan setiap Danramil untuk mendampingi Kyai Affifudin 
ketika ceramah agar suasana kondusif dapat tercapai (Suara Merdeka, 15 Juli 1998).

Ketiga, upaya rekonsiliasi juga diupayakan oleh Pengurus Cabang NU Jepara, melalui media pengajian umum dan menghadirkan mubaligh yang belum terkontaminasi politik untuk memberikan pencerahan kepada masyarakat. Isi ceramah tidak membahas masalah politik namun lebih kepada peningkatan iman dan ukhuwah islamiyah (Wawancara dengan Muhammadi Kosim, 22 Mei 2015). Pengajian dilakukan secara reguler hingga tingkat desa. Pengurus NU juga menurunkan Banser (Barisan Serba Guna) sebagai pengamanan di masyarakat agar kerusuhan yang sama tidak terulang kembali. Namun upaya yang dilakukan pengurus NU tersebut tidak mendapat dukungan penuh masyarakat, malah masyarakat mencurigai ada motif untuk memobilisasi massa untuk pindah ke partai yang akan didirikan oleh kalangan NU (Wawancara dengan Thoha Makmum, 26 September 2015).

\section{SIMPULAN}

Peristiwa 7 Juli 1998 merupakan bentuk kulminasi dari konflik antar pendukung partai Islam di Jepara. Konflik tersebut tidak terlepas dari pengaruh Nahdlatul Ulama (NU) dalam membentuk sikap politik masyarakat Islam Jepara. Islam dimaknai oleh masyarakat Jepara tidak hanya sebagai ajaran religi semata namun telah menjadi sebuah pandangan politik. Keberadaan ulama atau Kyai dalam masyarakat Jepara memiliki peran cukup penting dalam mempengaruhi kehidupan religi, budaya, sosial kemasyarakatan dan politik.

Kerusuhan 7 Juli 1998 dipicu adanya pro-kontra di dalam masyarakat Jepara terhadap kehadiran kyai yang isi ceramahnya cenderung provokatif. Namun hal tersebut merupakan puncak dari adanya konflik antar pendukung partai politik di Jepara. Faktor yang mempengaruhi yaitu politisasi agama oleh tokoh-tokoh partai dengan memanfaatkan kyai untuk menarik dukungan massa. Dalam masyarakat Jepara, sosok kyai memiliki peran yang cukup penting selain di bidang religius, kyai ikut terlibat dalam kegiatan politik.

Berakhirnya kekuasaan orde baru dan munculnya reformasi menyebabkan euforia politik. Kesamaan basis massa yang digarap oleh beberapa partai membuat terjadi perebutan pengaruh massa yang sama yaitu massa NU. Adanya aksi kontra terhadap kehadiran kyai yang dianggap provokatif dan munculnya isu dimasyarakat Jepara memicu terjadinya gerakan massa pada 7 Juli 1998 yang berakhir pada kerusuhan.

Dampak kerusuhan 7 Juli 1998 di Jepara meliputi dampak fisik berupa kerusakanakibatkerusuhan, serta dampak psikologis bagi masyarakat Jepara berupa trauma. Selain itu hubungan sosial antar masyarakat di Jepara menjadi renggang dan saling curiga karena perbedaan pandangan politik.

Upaya penanganan kerusuhan yaitu dengan dialog antara aparat pemerintah yang terdiri dari kepolisian dan TNI serta tokoh PPP, Tokoh NU, Muhammadiyah, Gereja dan DPRD Jepara untuk mebicarakan agar kerusuhan yang terjadi sehari sebelumnya tidak terulang kembali. Upaya penanganan pasca kerusuhan terus dilakukan oleh pihak kepolisian melalui pendekatan terhadap Kyai Affifudin untuk membicarakan solusi dan jalan keluar mengenai kerusuhan di Jepara. Upaya rekonsiliasi juga diupayakan oleh Pengurus Cabang NU Jepara, melalui media pengajian umum dan menghadirkan mubaligh yang belum tekontaminasi politik untuk memberikan pencerahan kepada masyarakat.

Jurnal Multikultural \& Multireligius Vol. 19 No. 2 


\section{UCAPAN TERIMAKASIH}

Penulis mengucapkan terima kasih kepada semua pihak yang membantu dalam terlaksana dan tersajinya hasil penelitian ini, utamanya para informan kunci dan masyarakat Jepara, Dr. Alamsyah pembimbing penulis di Universitas Diponegoro, Dr. Widjajanti, Prof. Endang Turmudi, Prof. Alie
Humaedi, Prof. Dwi Purwoko, Prof. M. Hisyam yang membimbing penulis untuk terus berkarya. Penulis juga menyampaikan terima kasih kepada redaktur dan mitra bestari Jurnal Harmoni yang berkenan membaca dan memberikan koreksi yang sangat membangun. 


\section{DAFTAR ACUAN}

Abdullah, T. (1990). Sejarah lokal di Indonesia: kumpulan tulisan. Yogyakarta: Gadjah Mada University Press.

Achidsti, S. A. (2015). Kyai dan Pembangunan Institusi Sosial. Pustaka Pelajar.

Ahnaf, M. I., \& Suhadi, S. (2014). Isu-isu Kunci Ujaran Kebencian (Hate Speech): Implikasinya terhadap Gerakan Sosial Membangun Toleransi. Harmoni, 13(3).

Bisri, M. C. (1999). Ketika nurani bicara. Bandung: Remaja Rosdakarya.

Dhofier, Z. (1982). Tradisi pesantren: Studi tentang pandangan hidup kyai. Lembaga Penelitian, Pendidikan, dan Penerangan Ekonomi dan Sosial.

Garraghan, G. J. (1946). A guide to historical method: Garraghan. Fordham University Press.

Gottschalk, L., \& Notosusanto, N. (1985). Mengerti sejarah. Jakarta: Penerbit Universitas Indonesia.

Hajati, C., \& Kartodirdjo, A. S. (1990). Peristiwa Cimareme tahun 1919:: Perlawanan H. Hasan terhadap peraturan pembelian padi. Yogyakarta: Universitas Gadjah Mada.

Haris, S. (1991). PPP dan politik Orde Baru. Gramedia Widiasarana Indonesia.

Horikoshi, H. (1987). A Traditional Leader in a Time of Change: The Kijaji and Ulama in West Java, terj. Umar Basalim Dan Andi Muarly Unrawa Dalam Kyai Dan Perubahan Sosial.

Humaedi, M. A. (2015). Mengislamkan Jawa: Sejarah Islamisasi di Jawa dan Penentangnya dari 1930 sampai Sekarang Karya MC Ricklefs. Harmoni, 14(1), 184-197.

Indonesia, K. B. B. (2005). Edisi ketiga. Jakarta: Balai Pustaka.

Jepara, B. (1998). Jepara dalam Angka tahun 1998. Bappeda Kabupaten Jepara.

Kartodirjo, S. (1982). Pemikiran dan perkembangan historiografi Indonesia: suatu alternatif. Gramedia.

Khalik, R. N. (2016). NU dan Bangsa (1914-2010) Pergulatan Politik dan Kekuasaan. Yogyakarta: Ar-Ruzz Media. Cetakan III.

Marijan, K. (2019). Sistem politik Indonesia: konsolidasi demokrasi pasca Orde Baru. Kencana.

Miall, H. (2000). Resolusi Damai Konflik Kontemporer: Menyelesaikan, Mencegah, Mengelola dan Mengubah Konlik Bersumber Politik, Sosial, Agama dan Ras, terj. Tri Budhi Sastrio. Jakarta: PT Raja Grafindo Persada.

Moesa, A. M. (2007). Nasionalisme Kyai; Konstruksi Sosial Berbasis Agama. LKIS Pelangi Aksara.

Muhtadi, A. S. (2004). Komunikasi politik Nahdlatul Ulama: pergulatan pemikiran politik radikal dan akomodatif. LP3ES.

Nurdiyanto. (2004). Kerusuhan di Pekalongan, Jawa Tengah. Kementerian Kebudayaan dan Pariwisata.

Sahidin. (2001). Konflik Antar Pendukung Partai Politik: Studi Kasus Kekerasan Massa di Dongos Jepara. Universitas Gadjah Mada Yogyakarta. 
Schiller, J. W. (1996). Developing Jepara: state and society in new order Indonesia (Issue 40). Monash Asia Inst.

Shobron, S. (2003). Muhammadiyah dan Nahdlatul Ulama Dalam Pentas Politik Nasional.

Singh, R. (2010). Gerakan Sosial Baru. Yogyakarta: Resist Book.

Smelser, N. J. (2011). Theory of collective behavior. Quid Pro Books.

Sukamto. (1999). Kepemimpinan Kyai dalam pesantren. Lp3es.

Suryo, D. (2000). Tradisi Santri dalam Historiografi Jawa, Pengaruh Islam di Jawa. Seminar Pengaruh Islam Terhadap Budaya Jawa, Jakarta.

Syamsuddin, M. (2013). Kyai dan politik: keterlibatan Kyai madura dalam politik praktis. Jurnal Sosiologi Reflektif, 7, 47-72.

Tim Sekretaris Negara. (1983). 30 Tahun Indonesia Merdeka Jilid 1. Jakarta: Tira Pustaka.

Turmudi, E. (2000). Reformasi dan Konflik Politik antar Pendukung Partai Islam: Studi Kasus di Jepara. Masyarakat Indonesia, 26(1), 137-159.

Turmudi, E. (2004). Perselingkuhan Kyai dan kekuasaan. PT LKiS Pelangi Aksara.

Turmudi, E. (2016). Islamic Twists and The Decline of Islamism In Indonesia. Harmoni, 15(3), 161-172.

Zazeri, A. (2007). Kerusuhan Sosial di Desa Dongos Kecamatan Kedung Kabupaten Jepara Tahun 1999 (Suatu Kajian Sejarah Sosial). Universitas Negeri Semarang.

Surat Kabar

Gatra (Jakarta), 18 Juli 1998.

Kompas (Jakarta), 8 Juli 1998 ; 19 januari 2002.

Pikiran Rakyat (Jawa Barat), 9 Juli 1998.

Republika (Jakarta), 9 Juli 1998.

Suara Karya (Jawa Tengah), 9 Juli 1998.

Suara Medeka (Jawa Tengah), 15 Juli 1998; 11 Juli 1998; 14 Juli 1998; 15 Juli 1998; 8 Juli 1998; 8 Juli 1998; 9 Juli 1998; 13 Juli 1998; 8 Juli 1998.

Jawa Post (Jawa Timur), 10 Mei 1999.

\section{Daftar Informan}

Affifudin, 10 Maret 2015

Siti Arifah, 26 September 2015

Harsono, 20 Maret 2015

Mahbub Junaidi, 22 Mei 2015

HARMONI | Juli - Desember 2020 
Darsono, 20 Maret 2015

Suprianto, 21 Mei 2015

Muhammadi Kosim, pada 22 Mei 2015

Pramudyi pada 19 September 2015

Hadi Priyanto pada 25 Mei 2015

Maskury Rosyid, 1 September 2015

Abdul Rosyid, 19 September 2015

Sumarno, 19 September 2015

Ali Rosyid, 19 September 2015

Ahmad Sholeh, 26 September 2015

Ahmad Thoha Makmum Ma'shum 26 September 2015 